\title{
60
}

\section{Computer-supported Workplace Learning}

\author{
Bente Elkjaer \\ Department of Informatics, Copenhagen Business School, Howitzvej 60, DK-2000 \\ Frederiksberg, Denmark \\ elkjaer@cbs.dk
}

Keywords: in-service training, lifelong learning education, vocational education

\begin{abstract}
This paper deals with the following conceptual issues: What is workplace or organisational learning? What is learning? What is computer-supported learning? And what is computer-supported organisational learning? The grounds for dealing with these issues are an empirical study on the organisation of IT-supported workplace learning. This study shows that there are many ways of organising IT-supported education in organisations ranging from IT-training to training that results in different kinds of certificates to highly specialised university degrees via distance learning. In conclusion, the paper suggests that there is a need to develop new models for computersupported workplace learning based on the concrete organisational work practices and the information systems employed by the organisation.
\end{abstract}

\section{INTRODUCTION}

Results of surveys show a gradual increase in the use of information technology (IT) for educational purposes in Danish private enterprises (IFKA 1996-2000). Thus, in 1995 a third (32\%) of Danish enterprises applied IT for educational purposes, while the number in 1999 included more than half the enterprises $(55 \%)$. The surveys were ordered by the Centre for Technology-Supported Education (CTU), a Danish organisation to further computer-supported education. For five years, CTU employed a consulting firm, Institute for Konjunktur-Analyse (IFKA), to make the surveys. The objectives were to find out how many enterprises applied IT for 
educational purposes, why and for what specific purposes. The surveys were based upon 600 telephone interviews with the persons in charge of education and training in a representative sample of Danish private enterprises.

Private Danish enterprises apply IT for educational purposes to enhance the general level of IT competencies, to save time and money and to improve flexibility in time and space regarding education and competence development. Thus, computer-supported education has mainly focused on IT itself, and in 1999 more than half the enterprises used their computersupported education on PC driver's licenses and other computer training courses. The surveys do not indicate how the enterprises organise their computer-supported education and what sort of workplace learning computer-supported workplace education provides.

The lack of information about the organisation of computer-supported workplace education and the actual learning outcome was the reason why I contacted CTU and proposed a collaborative project on computer-supported workplace learning. The method implied that IFKA should ask some of the enterprises that in 1999 applied IT for educational purposes to participate in an interview conducted by me. The enterprises should have less than 100 employees and be situated in Zealand or in the Greater Copenhagen area. Apparently, this was not an easy delimitation as I had enterprises with several thousands employees on my list.

In this paper, I report on the study making tentative conclusions and suggesting further research based on the study itself, but also on the theoretical landscape of the domain, computer-supported workplace learning. As the domain has yet to be defined, I include theories on the workplace as a context for learning in addition to general theories on learning, computer-supported learning and computer-supported organisational learning. In conclusion, I suggest that more studies need to be made on workplaces where computer-supported workplace learning is viewed in light of the overall learning activities in an organisation, including the information systems applied to share knowledge. The latter is included to ensure that unintentional learning in workplaces is considered and viewed as part of the overall organisational learning.

\section{RESEARCH AND RESULTS}

79 enterprises met the criteria established by me, but only 18 wanted to participate in the study (Elkjær and Olsen 2001a, Elkjær and Olsen 2001b). The reason why only about $25 \%$ of the contacted enterprises wanted to participate is unclear, but probably Danish enterprises get a great many calls asking them to participate in different surveys, etc. I contacted the persons in 
charge of education and training in the enterprises - the same persons that IFKA had contacted previously. In 3 out of the 18 enterprises, I was already told on the phone that they did not apply IT for educational purposes (maybe because I used the term "computer-supported learning" rather than "application of IT for educational purposes"). In another enterprise, the contact person had changed to another job, and finally I included one large enterprise that was not part of the original sample. All in all, I interviewed 15 people in 15 enterprises. In the interviews, I asked them about the organisation and the content of their computer-supported workplace education. I also asked them to assess the benefits and problems related to learning in connection with computer-supported education in the workplace.

Out of the 15 interviewed enterprises, 7 did not apply computers for intentional educational activities. The other half of the enterprises (8) had either organised the education as individual home-based learning, with or without an on-line tutor or teacher, or as work-based learning. The workbased computer-supported education was either organised as individual learning in a separate room, learning from the employees' own work-stations or teaching in groups or classes with live or on-line access to a teacher and peers.

On the one hand, the content of the computer-supported education aimed at providing identical training for the great majority. For example, training resulting in a PC driver's license and other kinds of certificates. The latter was the case in large industries (and groups) with many specific quality standards, e.g. enterprises that were part of a group or industry such as the pharmaceutical industry, in which many conventions in research and production must be followed according to agreement. These enterprises are large enough or may co-operate within their industry to develop computersupported educational programs, which, in turn, enable many employees to obtain specific certificates through the use of jointly developed CD-ROMs or Internet-based Computer-Based Training (CBT). On the other hand, the Internet provides a huge market for specialist education in demand by enterprises that survive on their competitiveness to be innovative. Such enterprises can e.g. be found within tele-communication. These two extremes within computer-supported education may exist within the same enterprise, but they have different employees as target groups. Thus, enterprises working in very competitive environments see the Internet as a huge market place where their demand for highly specialised competencies can be met and where they can procure highly qualified education for their professionals. In other words, computer-supported education is a way in which to provide both certificates for the great majority and specialised education for the few. 
There was a certain apprehension about whether learning benefits could be derived from applying computer-supported education in introductory teaching. It was, for example, difficult to learn programs (e.g. the modules in the PC driver's license) that the learner had never used before. This was the reason why computer-supported education was not used in introductory education within for example quality. Another problematic aspect of computer-supported education was the lack of personal contact to a teacher or tutor. Individually based computer-supported education without contact to a teacher or co-learners require a great deal of self-discipline regardless of whether the training takes place at home or in the office. An advantage in computer-supported education was the 'private' learning-room around the computer. It appeared to have a beneficial effect on employees who were not so school-minded as it allowed them to operate in a room of learning without being subject to (negative) judgments. This assessment was based on classroom teaching with access to a teacher.

On the one hand, organising computer-supported education as individual learning seems to be faced with problems of a motivational nature. On the other hand, the individual learning space around the computer seems to be beneficial in class-room organised computer-supported education. In this setting, the learner can ask a teacher without being subject to the social sanctions of a public learning space. The content of the computer-supported education was also mixed. It comprised both mass-produced and modulated CD-ROMs or Internet-based CBTs, including highly specialised education programs from the market selling teaching-programs.

The study was designed to provide an overview of the different ways in which computer-supported workplace education can be organised and to point out the benefits and problems in connection with such education. I believe, however, that it is necessary to adopt a broader perspective to see computer-supported workplace learning in the light of its venue, the workplace, and its tools, the organisational information systems. This is the background for including the following conceptual issue, the workplace as a context for learning, in addition to learning theories and theories of computer-supported learning and computer-supported organisational learning.

\section{THE WORKPLACE AS A VENUE FOR LEARNING}

In 1988, Zuboff coined the phrase "learning as the new form of labour" (Zuboff 1988, p. 395) based on knowledge as a prime asset in enterprises that employ IT beyond automation. Behind Zuboff's phrase is the contention 
that highly skilled computerised workplaces will require continuous organisational learning (see also Elkjaer 2000). Today, organisational learning is a notion that is widely accepted although there is no agreement on its meaning, which depends on the understanding of learning and organisational life and changes (Argyris and Schön 1996, Easterby-Smith 1997). Likewise, the term "workplace learning" is making its way into the domain of learning in organisations (Boud and Garrick 1999). An understanding of workplace or organisational learning (terms that I use indiscriminately) involves recognition of its complexities, its competing interests and the personal, political and institutional influences that affect it. In addition, it involves recognition of workplace or organisational learning as an issue between, on the one hand, organisation and management studies, and, on the other, educational studies and adult education (see also Tight 2000). This means that workplace learning draws upon very different academic fields and practical solutions.

A definition of workplace or organisational learning might be to view the workplace or organisation as a specific context. The workplace as a context sets some conditions for workplace learning. Furthermore, workplace learning is always directly or indirectly connected to the workplace practices, including the employees and the management who perform the work. Therefore, the activities around which learning unfolds are either an integral part of the work practices, of which the daily work consists, or they involve teaching, instruction or training that point towards these practices. In other words, workplace learning may be unintentional processes of learning in connection with work performance, but it may also be formally organised activities with explicit intentions to produce learning outcome. Following the attempt to define the context of computer-supported workplace learning, the next issue is to look at what learning is and what computer-supported learning may be as well as what it is.

\section{COMPUTER-SUPPORTED LEARNING}

The theoretical landscape of computer-supported learning reflects the general development of the dominant learning theories during the $20^{\text {th }}$ century. It may be described as a development from behaviourism focusing on the demands of an environment with fixed structures to cognitivism focusing on an organism's mental structures as fixed. The latter approach involves learning to solve problems by acquiring good reasoning methods through mental representations. The most recent paradigm within learning is a situated learning perspective or a transactional concept of learning that actually dates back to the work of John Dewey (1859-1952) (Bredo 1997, 
Dewey 1916, c.1966). In a transactional notion of learning, there are no fixed structures, and, thus, no boundary between organism and environment. Both organism and environment play a functional part in an activity. Thus, learning implies the creation of environments that can stimulate people to think and act 'mindfully' to solve relevant problems by way of experimenting. The focus of transactional learning comprises the whole life including feelings and emotions as opposed to the sole focus on cognition or behaviour. Transactional learning views learning as a social activity that takes place in communities, which implies that learning is relational and collaborative.

This development of learning theories can also be found in Koschman's (1996) overview of the paradigmatic development of computer-supported learning. Koschman identifies three past paradigms and one future paradigm for the instructional use of IT. The past paradigms are termed ComputerAssisted Instruction (CAI), Intelligent Tutoring Systems (ITSs), and Logoas-Latin Paradigm. Computer Supported Collaborative Learning, CSCL, may be the future paradigm for computer-supported learning. In the CAI paradigm, learning is viewed as the acquisition of a body of knowledge. The teacher's role is to find efficient ways of sharing knowledge and determine whether students have learned what they were taught. Instruction is a process of transmission or delivery. The strategy of CAI applications is to identify a specific set of learning goals, decompose the goals into a set of simpler component tasks and, finally, develop a sequence of activities designed to eventually achieve the original learning objectives. Although CAI is the oldest paradigm for computer application in education, it is by no means abandoned. The PC driver's license is an example of a CAI application.

The next paradigm, Intelligent Tutoring Systems (ITSs), was a direct result of an immigration of workers from the field of Artificial Intelligence (AI) into the educational area. The ITSs paradigm is based upon the Information Processing Theory in which problem solving is viewed as a process defining the representation of a problem space consisting of an initial state, a goal state, and a set of operations enabling movement from one state to another. Learning, in this light, is the process by which the problem solver acquires a proper representation of a problem space. Instruction consists of activities designed to facilitate the learner's acquisition of such a representation. The role of technology in the process is really not very different from the role it plays in the CAI paradigm. The differences are more in degree than in kind. In both cases, the designed application serves instruction by posing problems and providing the learner with feed-back. The difference is that ITSs aspire to employ a more interactive approach involving a more complex set of skills. 
The Logo-as-Latin paradigm originates in an epistemological perspective that looks at knowledge as acquired through a process of subjective construction on the part of the experiencing organism. This view of learning is referred to as constructivism and proposes that learning occurs through personal inquiry and discovery. Seymour Papert (1980), who argues that the activity of programming computers can play an important role in learning, provides an example of constructivism in computer-supported education. The construction of computer programs is particularly interesting in terms of learning because they can be executed. The assumption is that by engaging in the activities of programming, the learner acquires cognitive benefits that extend beyond simply learning to code in a particular language. A great deal of research within this paradigm involves learning to program in Logo, a powerful language designed in the mid-1960's for young children. Koschman has termed the paradigm the Logo-as-Latin Paradigm because it focuses on learning how to program in the service of more general educational objectives.

The central issue in constructivist research is cognitive self-organisation. It views the mind as a phenomenon residing within the head of the individual. CSCL is founded upon social constructivism that regards knowledge construction as an essentially social process in which learning is viewed as a process of entering into a community of practice (Lave and Wenger 1991). As an instructional technology, CSCL introduces a shift in reference leading to a foregrounding of the social and cultural context as the object of study. The model of instruction involved in CSCL is collaborative learning, i.e. learners are engaged in joint processes of learning. Technological applications to support collaborative learning are manifold and include all kinds of connecting technologies such as network, mediational and communication tools, tools for storage and for the support of co-operative knowledge construction.

When computer-supported learning enters the organisational world and becomes computer-supported organisational learning, it is often related to information processing and decision-making and as such becomes a matter of the organisational flow of information and knowledge. In literature on computer-supported organisational learning, learning tends to be viewed as comprising problem-solving, knowledge acquisition (or construction), distribution and application (Goodman and Darr 1998, Pentland, 1995). Computer-supported systems aimed to enhance organisational learning share features with traditional e-mail systems as e.g. the ability to bridge time and space. But they also differ by having a memory function and search facilities. The organisational memory is important in working with computer-supported organisational learning. It includes a joint understanding of an organisation's identity, the mental models that represent the 
organisational theories-in-use in addition to the cognitive and behavioural routines (Robey et al. 2000).

Using Koschman's paradigms, computer-supported organisational learning is grounded in the paradigm of ITSs and the Information Processing Theory. Computer-supported organisational learning seems to draw on learning as a process that constructs the representation of a problem space to solve organisational problems efficiently and to contribute to the organisational memory. It involves learning that relies on the organisational members' ability to apply replicable reasoning methods. In working with computer-supported organisational learning, the workplace is seldom viewed as a conflictual political scene. More often, the workplace is viewed as a fairly abstract entity consisting of streams of information and knowledge as well as mental representations in the minds of the organisational members.

\section{FURTHER RESEARCH}

I believe there is a need to develop new models for computer-supported workplace learning based on the concrete organisational work practices and the information systems applied in an organisation. This will imply a study of computer-supported workplace learning that is not based on an understanding of organisations as flows of information and knowledge, but on organisational members' use of the information systems at hand for their various needs. I also believe that to assess the benefits of computersupported education, it is necessary to view the learning as part of the whole organisational learning environment and not as isolated attempts to acquire specific skills and knowledge. This means that there is a need to study organisations as cases for workplace learning where computer-supported learning is seen as part of the overall learning activities, but also as part of the IT application as such in organisations. The latter includes the unintentional learning that is part of information sharing while working in and on the organisational work practices.

\section{REFERENCES}

Argyris, C. and Schön, D. A. (1996) Organizational Learning II. Theory, Method, and Practice. Addison-Wesley Publishing Company, Reading.

Boud, D. and Garrick, J. (eds.) (1999) Understanding Learning at Work. Routledge, London. Bredo, E. (1997) The Social Construction of Learning. In Handbook of Academic Learning. Construction of Knowledge, G. P. Phye (ed.), San Diego, Academic Press, pp. 3-43.

Dewey, J. (1916, c. 1966) Democracy and Education. An Introduction to the Philosophy of Education. The Free Press, New York. 
Easterby-Smith, M. (1997) Disciplines of Organizational Learning: Contributions and Critiques. Human Relations, 50 (9), pp. 1085-1113.

Elkjaer, B. (2000) Learning and getting to know: the case of knowledge workers. Human Resource Development International, 3 (3), pp. 343-359.

Elkjær, B. and Olsen, M. (2001 a) Virksomheders anvendelse af IT-støttet uddannelse muligheder og problemer (Enterprises' application of IT-supported educationpossibilities and constraints). Department of Informatics, Copenhagen Business School and Leaming Lab Denmark.

[http://www.ctu.dk/ctu/ctuwebsi.nsf/2c81d99d07e66774c12565e6003d89c4/fbe6101ecdad 5e75c12569de003cf3ab!OpenDocument].

Elkjær, B. and Olsen, M. (2001b) Virksomheders anvendelse af IT-støttet uddannelsemuligheder og problemer. Kommenteret bibliografi. Department of Informatics, Copenhagen Business School and Learning Lab Denmark. The bibliography (in Danish) can be downloaded here:

[http://www.ctu.dk/ctu/ctuwebsi.nsf/2c81d99d07e66774c12565e6003d89c4/7038d1dced8f f473c12569ec003b56a3/\$FILE/Bibliografi.pdf].

Goodman, P. S. and Darr, E. D. (1998) Computer-aided Systems and Communities: Mechanisms for Organizational Learning in Distributed Environment. MIS Quarterly, 22 (4), pp. 417-440.

IFKA (1996, 1997, 1998, 1999 and 2000) Informationsteknologi til uddannelse i private virksomheder (Information technology for educational purposes in private enterprises). [The reports can be found at CTU's home page: www.ctu.dk].

Koschman, T. (1996) Paradigm Shifts and Instructional Technology: An Introduction. In CSCL: Theory and Practice of an Emerging Paradigm, T. Koschmann (ed.) Lawrence Erlbaum Associates, Mahwah, NJ, pp. 1-23.

Lave, J. and Wenger, E. (1991) Situated Learning. Legitimate Peripheral Participation. Cambridge University Press, Cambridge.

Papert, S. (1980) Mindstorms. Basic Books, New York.

Pentland, B. T. (1995) Information Systems and Organizational Learning: The social epistemology of organizational knowledge systems. Accounting, Management and Information Technology, 5 (1), pp. 1-21.

Robey, D., Boudreau, M.-C. and Rose, G. M. (2000) Information Technology and Organizational Leaming: A Review and Assessment of Research. Accounting, Management and Information Technologies, 10 (2), pp. 125-155.

Tight, M. (2000) Critical Perspectives on Management Learning. A View from Adult/Continuing/Lifelong Education. Management Learning, 31 (1), pp. 103-119.

Zuboff, S. (1988) In The Age of the Smart Machine. The Future of Work and Power. Heinemann, New York.

\section{BIOGRAPHY}

Bente Elkjaer is an associate professor and the current Head of Department in the Department of Informatics at the Copenhagen Business School. She takes a special interest in computer-supported workplace learning from the perspective of both workplaces, and designers and suppliers of e-learning. 